\title{
Collaborative Learning in Authentic Environment Apps to Promote Preschool Basic Scientific Process Skills
}

\author{
$\underline{\text { https://doi.org/10.3991/ijim.v11i3.5774 }}$ \\ Mohd Amerul Akmal Mohd Yunos \\ Universiti Teknologi Malaysia, Johor, Malaysia \\ amerulfizik@yahoo.com \\ Noor Azean Atan \\ Universiti Teknologi Malaysia, Johor, Malaysia \\ azean@utm.my \\ Mohd Nihra Haruzuan Mohamad Said \\ Universiti Teknologi Malaysia, Johor, Malaysia \\ nihraeutm.my \\ Mahani Mokhtar \\ Universiti Teknologi Malaysia, Johor, Malaysia \\ p-mahani@utm.my \\ Norazrena Abu Samah \\ Universiti Teknologi Malaysia, Johor, Malaysia \\ norazrena@utm.my
}

\begin{abstract}
The use of mobile learning has rapidly gained popularity among students and this scenario has influenced students' learning styles. Hence, students prefer to use web-based learning, courseware and online apps in their learning. Based on the advantages of these mobile learning materials and findings of research which highlight their effectiveness in learning, a preschool learning apps known as AKSES was developed based on collaborative learning strategy in an authentic learning environment. Collaborative learning is one of the most effective learning strategies in crafting students' communication skills and providing supportive environment for students. Students have the opportunities to assist their peers during the T\&L process while indirectly communicating with each other. In addition, the concept of authentic learning refers to real learning based on actual situations and realities. Authentic learning exposes students to how a concept being materialised and applied in real life. A study was carried out to evaluate the effectiveness of AKSES and its impact on the preschool students' basic scientific process skills competency namely; observation, classification and communication. In addition, the study also investigated competency patterns of the students' skills. This study was a quantitative study which used two sets of instruments which looked into AKSES application and marking rubrics of the students' basic scientific process skills. Based on quasiexperimental study, the duration of the study was seven weeks and six learning activities were implemented. Two rural preschools were selected based on quo-
\end{abstract}




\begin{abstract}
ta sample selection and 25 students were in each controlled and treatment groups. Analysis of the survey data was carried out in the form of descriptive and inferential analysis involving Mann-Whitney $U$ test. The Mann-Whitney U test analysis found significant differences in competency patterns of basic scientific process skills in both groups. Meanwhile, the competency patterns of basic scientific process skills indicated positive increase among all preschool students after the utilization of AKSES application in learning activities based on collaborative learning strategy in an authentic environment.
\end{abstract}

Keywords-Mobile Learning, Authentic Learning, Collaborative Learning, Basic Science Process Skills

\title{
$1 \quad$ Introduction
}

The tactfulness of a teacher in determining the most effective and viable approach to be applied in T\&L process is essential. The applied teaching and learning strategy has to condone with the contemporary learning theories in assisting teachers to shape a more effective and structured learning space (Neo, 2010). For instance, real learning based on actual situations and realities is capable of exposing students as to how a concept materialised and applied in real life (Latham \& Carr, 2012).

To address the needs and demands of learning process that are closely related to the real world communication, authentic learning is one of the most effective ways in fulfilling the demands. The authentic learning process itself in actual leads to a definition that is in tandem with its approach whereby it maintains relevant learning relationship with the real world. (Tervakari \& Silius, 2011; Wilson \& Schwier, 2012).

According to Noor Azean (2012) authentic learning refers to a learning characterization that encompasses activities based on real situations with the application of skills and knowledge of a concept that ranges from problem-solving approach up to the authentic activity itself. Until recently, there is a number of relevant researches to authentic learning and its components as follow:

Notwithstanding, to achieve meaningful learning i.e. authentic learning environment, students have to also be exposed to a learning activity that encourages them to communicate and exchange opinions with one another (Dikkers, 2013a; Tham \& Tham, 2013; Woodley-Cook, Prabhudesai, \& Moloney, 2013)

Thus, there is another learning strategy that is capable of increasing students' communication level and other skills during the T\&L process such as collaborative learning strategy. According to Tham \& Tham (2013), collaborative learning is one of the most effective learning strategies in crafting students' communication skills. This strategy provides supportive platform for students to assist their peers during the T\&L process while indirectly communicating with each other. Hence, via the implementation of collaborative learning environment, it is capable of increasing one of the competency levels of scientific process that is communication skills.

According to Higgins et al. (2012), exchange of ideas in learning process shape students high interests towards a particular learning process besides capable of encouraging critical thinking through discussions and debates with pertain to the as- 
signed tasks. Group learning that encourages discussion on a certain learning information will generate positive impact towards students' memory retention on the discourse as compared to a student who learns individually (Fadjo, Friedman, Black, \& Johnson, 2012).

Nevertheless, apart from the abovementioned strategies, teachers would also have to consider alternative approaches in delivery of teaching information besides the traditional methodologies commonly applied in the classroom. This is to draw students' interests with particular to the young ones to understand the lesson easily and systematically in support for learning in authentic environment as well as the initiation of collaborative learning. In line with the technological advancement, it is deemed capable of assisting students to rapidly master the T\&L process (McManis \& Gunnewig, 2012).

According to Komis et al. (2013), majority of teachers are found to be less proactive in applying technology in teaching and learning process with their students. In addition, the use of technology in a classroom is capable of increasing students' focus and interests to give comprehensive attention along the teaching and learning process. Among the examples of technological application in teaching and learning process are web-based learning technology, multimedia application as well as the currently expanding touch-screen technology widely known as mobile application (app).

Therefore, teachers have to identify the needs and lacks in teaching and learning process to ensure that the teaching and learning strategies being utilized are feasible so as not to burden students' cognitive level. This may results in effective and structured learning environment apart from the capability to apply the current technology into the teaching and learning system (Auzar, 2012). Besides increasing visionary human capital and students' potential, it will also create a new learning environment to students.

The world of technology and education is inseparable nowadays due to developments of researches that combines the two mainstreams into a solid system. It is seen as capable in helping to increase students' required skills as in the preschool learning that involves inculcation of scientific process (Lati, Supasorn, \& Promarak, 2012; Turiman et. al., 2012).

\section{Materials and Methods}

This research was designed in the form of Quantitative Research i.e. quasiexperimental design. According to Hoe and Hoare (2012), quantitative research technique is applied to evaluate or test a hypothesis, determining relationship between variables and to measure frequency of observation.

Additionally, quantitative data can be quantified or measured and one of the examples of this method is through questionnaires and review (Creswell, 2008). With reference to Griffith (2014) as well as Campbell and Stanley (1963), quasi-experimental research design takes the form of comparison between two groups that are treatment group and controlled group. Quasi-experimental research design also identifies rela- 
tionship between independent variable and dependent variable (Chua, 2011; Shadish, Cook, \& Campbell, 2002).

Quasi-experimental research design was selected to view the variable effect (AKSES app) to the treatment group and conventional learning approach to the controlled group (Chua, 2011; Piaw, 2011). As the results, only two classes were involved and selected for this research through quota sampling technique based on their similarity in backgrounds and characteristics. According to Chua (2011) the nonequivalent groups' pre-post tests design, i.e. selection of samples is non-random for both treatment and controlled groups that have closely similar characteristics.

This research involved 2 types of instruments i.e. AKSES application and marking rubrics of students' competency in basic scientific process. Figure 3.2 elucidates the shape of research design pattern in the form of pre-post test design utilized during the content and questionnaire-based pre and post tests towards students' learning of science on the basis of basic scientific process skills in an authentic learning environment.

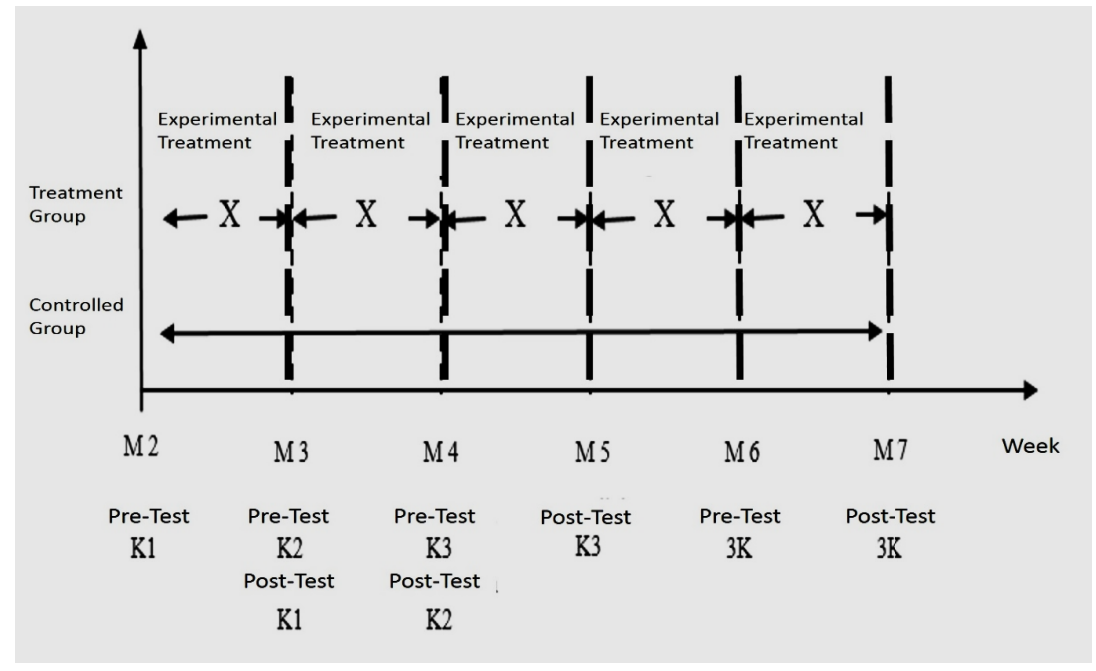

$$
\begin{gathered}
\text { K1: Observation Skills } \\
\text { K2: Classification Skills } \\
\text { K3: Communication Skills }
\end{gathered}
$$

3K: Observation, Classification and Communication Skills

Fig. 1. Pattern of Non-Equivalent Groups Design

The mobile apps was developed using Adobe Flash CS6, Adobe illustrator and Advance Audio Recorder Beta. The final apps named AKSES that have been developed was uploaded in the Google Play Store.

In this study, there were three research instrument involved which are pre-post-test (for content), questionnaire on students perception towards using AKSES apps in learning Science. An interview question was developed to get further in-depth of the students perception towards the AKSES apps. 


\section{Tables and Results}

The following tables display findings of analysis for marking rubrics on preschool's basic scientific skills competency in authentic environment. Evaluations that were carried out by 2 teachers and the researchers were based on 3 core skills i.e. observation skills, classification skills and communication skills. A total 25 students from the controlled group and 25 other students from the treatment group were fully involved in this evaluation process. Overall, the evaluation and treatment process involved seven weeks describe as Figure 1.

\subsection{Analysis on Observation Skills}

Table 1 is the analysis of findings on observation skills for controlled group and treatment group.

Table 1. Mann-Whitney U Test Analysis on Observation Skills

\begin{tabular}{|l|c|c|c|c|}
\hline \multicolumn{2}{|c|}{ Group } & N & Min & Sum of Ranks \\
\hline \multirow{3}{*}{$\begin{array}{c}\text { Post Observa- } \\
\text { tion Test }\end{array}$} & Controlled & 25 & 13.00 & 325.00 \\
\cline { 2 - 5 } & Treatment & 25 & 38.00 & 950.00 \\
\cline { 2 - 5 } & Total & 50 & & \\
\hline \multicolumn{2}{|c|}{} & \multicolumn{2}{c|}{ Post Test } \\
\hline \multicolumn{2}{|c|}{ Mann-Whitney U } & \multicolumn{2}{c|}{0.000} \\
\hline \multicolumn{2}{|c|}{ Asymp. Sig. (2-tailed) } & .000 \\
\hline
\end{tabular}

Significant value $\mathrm{p}=0.000$ was smaller than the significant value $\alpha$ i.e. 0.05 $(p<0.05)$. Therefore, it can be concluded that utilization of AKSES application in learning based on collaborative learning strategy in authentic environment was capable of demonstrating better level of observation skills competency compared to conventional learning.

\subsection{Analysis on Classification Skills}

Table 2 is the analysis of findings on classification skills for controlled group and treatment group.

Table 2. Mann-Whitney U Test Analysis on Classification Skills

\begin{tabular}{|c|c|c|c|c|}
\hline \multicolumn{2}{|c|}{ Group } & N & Min & Sum of Ranks \\
\hline $\begin{array}{c}\text { Post Classifi- } \\
\text { cation Test }\end{array}$ & Controlled & 25 & 17.04 & 426.00 \\
\cline { 2 - 5 } & Treatment & 25 & 33.96 & 849.00 \\
\cline { 2 - 5 } & Total & 50 & & \\
\hline \multicolumn{4}{|c|}{ Mann-Whitney U } & 101.000 \\
\hline Asymp. Sig. (2-tailed) & .000 \\
\hline
\end{tabular}


Significant value $p=0.000$ was smaller than the significant value $\alpha$ i.e. 0.05 $(\mathrm{p}<0.05)$. Therefore, it can be concluded that utilization of AKSES application in learning based on collaborative learning strategy in authentic environment was capable of demonstrating better level of classification skills competency compared to conventional learning.

\subsection{Communication Skills Analysis}

Table 3 is the analysis of findings on communication skills for controlled group and treatment group.

Table 3. Mann-Whitney U Test Analysis on Communication Skills

\begin{tabular}{|c|c|c|c|c|}
\hline \multicolumn{2}{|c|}{ Group } & \multirow{2}{*}{$\begin{array}{c}\mathbf{N} \\
25\end{array}$} & \multirow{2}{*}{$\begin{array}{c}\text { Min } \\
15.00\end{array}$} & \multirow{2}{*}{$\begin{array}{r}\text { Sum of } \\
\text { Ranks } \\
375.00\end{array}$} \\
\hline Post Communica- & Controlled & & & \\
\hline tion Test & Treatment & 25 & 36.00 & 900.00 \\
\hline & Total & 50 & & \\
\hline & & & \multicolumn{2}{|c|}{ Post Test } \\
\hline \multicolumn{3}{|c|}{ Mann-Whitney $U$} & \multicolumn{2}{|c|}{50.000} \\
\hline \multicolumn{3}{|c|}{ Asymp. Sig. (2-tailed) } & \multicolumn{2}{|c|}{.000} \\
\hline
\end{tabular}

Significant value $\mathrm{p}=0.000$ was smaller than the significant value $\alpha$ i.e. 0.05 $(\mathrm{p}<0.05)$. Therefore, it can be concluded that utilization of AKSES application in learning based on collaborative learning strategy in authentic environment was capable of demonstrating better level of communication skills competency compared to conventional learning.

\subsection{Analysis on Competency Patterns of Preschool's Basic Scientific Process Skills}

Figure 2 elucidates patterns derived from students' competency of preschool's basic scientific skills. From Figure 2, it could be deduced that there were eight forms of students' competency pattern of preschool's basic scientific process skills i.e. first: 3-3-3, second: 3-3-2, third: 3-3-1, fourth: 3-2-3, fifth: 3-2-2, sixth: 3-2-1, seventh: $3-$ 1-2, and eighth: 3-1-1. These forms elucidated that each student possesses different competency patterns of basic scientific process skills.

This explained that the treatments given to the students had successfully produced various competency patterns based on collaborative learning strategy in authentic learning environment. 


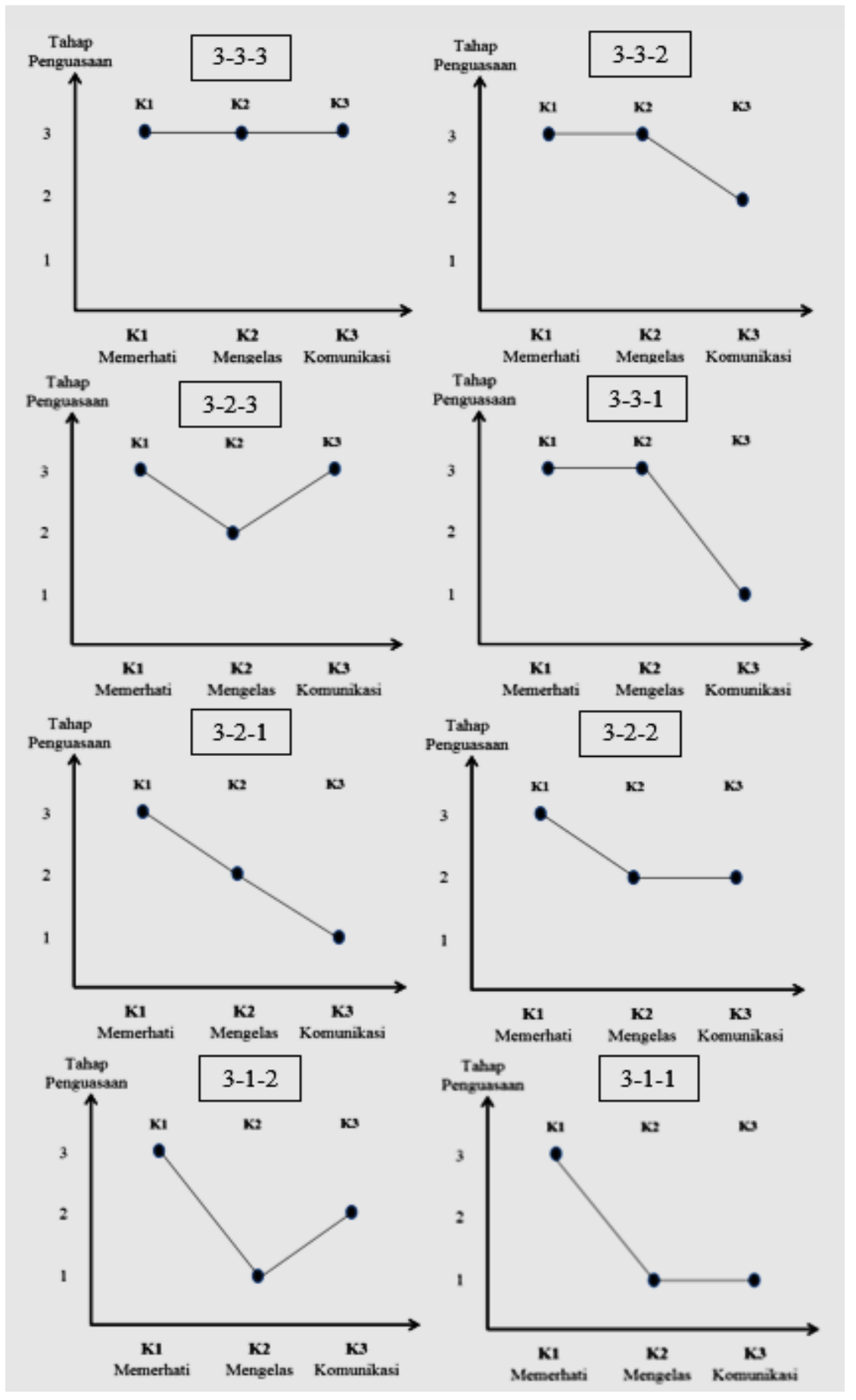

Fig. 2. Competency Patterns of Preschool's Basic Scientific Process Skills 


\section{Discussions}

The 3 main tables i.e. Tables 1, 2 and 3 were accordingly referred to in discussing students' competency in preschool's basic scientific skills. Those tables respectively represented the findings of data analysis towards 3 core skills of scientific process which comprise of observation, classification and communication.

A total of 25 students represented the controlled group while another 25 students membered the treatment group that ultimately summed up to 50 students in grand total. Each group's competency in basic scientific skills was differentiated through utilization of AKSES application in learning activities for the treatment group, whereas the traditional learning approach was applied on the controlled group.

With reference to Table 1, the post test demonstrated difference in min value of the competency score for observation skills in both groups. The competency score for the treatment group was noticeably higher than the controlled group with min values of 38 and 13 respectively. Significant change in min values for both treatment and controlled groups was also perceived in the score for classification skills in Table 2 with min values of 33.96 and 17.04 .

Similarly, Table 3 also recorded high difference in min values for communication skills i.e. 36 for the treatment group and 15 for the controlled group. The significant difference in min values as seen in treatment and controlled groups was likely due to the nature of learning activities imposed on each group. Precisely, learning activities based on AKSES application technology imposed in the treatment group generated positive impact towards students' learning interests.

This factor had eventually contributed to the difference in min values for both groups. The findings were also agree that the utilization of technology-based learning materials can generate good impact towards students' learning interests. Therefore, it had indirectly improved the observation skills that were positively correlated with students' interests in learning Science. Sharifah and Kamarul (2011) echoed similar opinion that maximum use of technological tools helps to increase students' motivation towards learning process.

Besides that, classification skills are closely related with students' ability to understand the concepts and information taught in learning activities. It can be summarized from this correlation that if students are interested to study, it would be indirectly easier for them to memorize and comprehend the lessons in the classroom.

This was collectively agreed by Okamoto and Kayama (2004), which stated that learning aided by technological tools can increase students' capacity to remember as well as their memory of the subject matter and information learned. Hence, it was demonstrated that the competency of classification skills in the treatment group was higher than the controlled group.

Sandberg (2002) as well as McManis and Gunnewig (2012) reported in their research that utilization of technological tools is beneficial in learning process among preschool students due to its high potential in supporting their development besides capable of increasing social and cognitive skills. Indirectly, the implementation of collaborative learning in authentic environment will support the development of the young minds through group discussions in collaborative learning activities to encour- 
age higher level of thinking through exchange of ideas and communication skills among students (Teras et. al., 2012; Asiri, 2013).

Through analysis of the research findings demonstrated in Table 3 , it could be noticeably inferred that the treatment group demonstrated significantly better communication skills between controlled group and treatment group. The inculcation of collaborative learning strategy in authentic environment was seen as very effective in increasing students' communication skills.

This had been equally approved by Slotte and Tynjala (2005) as well as Amory (2013) which stated in their researches that collaborative learning is one of the learning processes that nurture effective communication skills among students. Hence, analysis of the findings clearly inferred that collaborative learning is capable of shaping students' communication skills competency albeit in preschool level.

The skills competency patterns were shaped based on preschool's basic scientific process skills competency table (refer Table 5.10). As the results, eight competency patterns of preschool basic scientific process skills were gained with one pattern demonstrated competency of all 3 skills with full mark, three patterns illustrated competency of 2 skills with full mark and the remaining four patterns portrayed competency of only 1 skill with full mark.

The best pattern is demonstrated by total competency of all 3 skills (3-3-3) with full mark, while good competency indicates mastery of 2 skills with full mark (3-3-2; $3-2-3 ; 3-3-1)$ and weak competency involves mastery of only one skill with full mark $(3-2-1 ; 3-2-2 ; 3-1-2 ; 3-1-1)$. If the competency pattern is carefully examined, it can be found that all students proficiently gained competence in observation skills with full mark. This had clearly shown that AKSES application could draw students' interests and attention towards Science subject.

According to Martin-Dorta, Saorin, and Contero (2011) utilization of touch screen applications is crucial for students' cognitive and social development particularly in children. Besides, it encourages students' attention towards the learning process and this is proven through the findings of this research which were demonstrated in students' observation skills competency (observatory) and increase in commendable achievements through the content-based pre-post tests.

Based on the comparison, it could also be inferred that students' competency in basic scientific process and mastery of skills in scientific project is directly correlated. For students who obtained full mark in all three skills of basic scientific process (3-33 ), they were also recorded to have gained full mark (3) in their scientific projects while students who obtained the weakest competency (3-1-1) recoded only a minimum score (1). Nevertheless, although the skills competency scores were vary in each individual student, the overall competency achievement was recorded at good level, i.e. minimum grade of $\mathrm{B}$.

Notwithstanding, if comparisons were to be made on the findings based on the interviews done by the preschool teachers pertaining to students' competency problems against basic scientific skills, merely a few students managed to master only 1 or 2 skills. However, this research was successful in producing students who are substantially competent in all of the skills whereby almost half of them were able to master 
more than two skills proficiently. This was considerably a good achievement for preschool students who learned Science subject for the first time.

\section{$5 \quad$ References}

[1] Amory, A. (2013a). The Collaboration-Authentic Learning-Tool Mediation (CAT) Framework: Shifting from a Paradigm of Training towards an Activity Theory-based Developmental Approach. Paper presented at the World Conference on Educational Multimedia, Hypermedia and Telecommunications 2013, Victoria, Canada. http://www.editlib.org/p/112158

[2] Asiri, Y. A. (2013). Evaluation of mobile touch-based collaboration interaction styles to enhance spatial abilities and practice learning for children. (1537268 M.S.), University of Wyoming, Ann Arbor. Retrieved from https://vpn.utm.my/docview/1362253346 ?accountid $=41678$ ProQuest Dissertations \& Theses Full Text database.

[3] Auzar. (2012). Keberkesanan Penggunaan Perisian Asas Membaca. GEMA Online ${ }^{\mathrm{TM}}$ Journal of Language Studies, 12(2), 629-644.

[4] Campbell, D. T., \& Stanley, J. C (1963). Experimental and Quasi-Experimental Designs for Research. Houghton Mifflin Company Boston. 1st Edition, 1-34

[5] Chua, Y. P. (2011). Research methods and statistics book 2: Statistics basic Research methods and statistics book 2: Statistics basic (Vol. 2): McGraw-Hill Education.

[6] Creswell, J. W. (2008). Educational Research: Planning, Conducting, and Evaluating Quantitative and Qualitative Research (3rd ed.). Upper Saddle River, New Jersey: Pearson Education Inc.

[7] Dikkers, S. (2013a). Mobile Media Learning: Amazing Uses of Mobile Devices for Learning. Paper presented at the Society for Information Technology \& Teacher Education International Conference 2013, New Orleans, Louisiana, United States. http://www.editlib.org/p/48340

[8] Fadjo, C., Friedman, B., Black, J., \& Johnson, L. (2012). Improving Reading Comprehension Skills Using A Touch-Based Interactive Mobile App. Paper presented at the Society for Information Technology \& Teacher Education International Conference 2012, Austin, Texas, USA. http://www.editlib.org/p/39962

[9] Griffith, J. D. (2014). A Quasi-Experimental Comparison of Student Satisfaction in Hybrid versus and Online-Only Course. (3579722 Ph.D.), Northcentral University, Ann Arbor. Retrieved from https://vpn.utm.my/docview/1510627841 ?accountid=41678 ProQuest Dissertations \& Theses Global database.

[10] Higgins, S., Mercier, E., Burd, L., \& Joyce-Gibbons, A. (2012). Multi-touch tables and collaborative learning. British Journal of Educational Technology, 43(6), 1041-1054 https://doi.org/10.1111/j.1467-8535.2011.01259.x

[11] Hoe, J., \& Hoare, Z. (2012). Understanding quantitative research: part 1. Nursing Standard (Royal College Of Nursing (Great Britain): 1987), 27(15-17), 52-57. https://doi.org/10.7748/ns2012.12.27.15.52.c9485

[12] Komis, V., Tzavara, A., Karsenti, T., Collin, S., \& Simard, S. (2013). Educational scenarios with ICT: an operational design and implementation framework. Paper presented at the Society for Information Technology \& Teacher Education International Conference 2013, New Orleans, Louisiana, United States. http://www.editlib.org/p/48594

[13] Latham, G., \& Carr, N. (2012). Authentic Learning for Pre-Service Teachers in a Technology-Rich Environment. Journal of Learning Design, 5(1), 32-42. https://doi.org/10.5204/ jld.v5i1.101 
[14] Lati, W., Supasorn, S., \& Promarak, V. (2012). Enhancement of Learning Achievement and Integrated Science Process Skills Using Science Inquiry Learning Activities of Chemical Reaction Rates. Procedia - Social and Behavioral Sciences, 46(0), 4471-4475. doi: https://doi.org/10.1016/j.sbspro.2012.06.279

[15] Martin-Dorta, N., Saorin, J. L., \& Contero, M. (2011). Web-based Spatial Training Using Handheld Touch Screen Devices. Educational Technology \& Society, 14(3), 163-177.

[16] McManis, L. D., \& Gunnewig, S. B. (2012). Finding the Education in Educational Technology with Early Learners. Technology and Young Children.

[17] Neo, M., Neo, K. T.-K., \& Tan, H. Y.-J. (2011). Content Restructuring with Authentic Learning Strategies in a Multimedia Learning Environment (MMLE). Paper presented at the World Conference on Educational Multimedia, Hypermedia and Telecommunications 2011, Lisbon, Portugal. http://www.editlib.org/p/38170

[18] Noor Azean Atan. (2012). Profil Kontinum Pemikiran Visual Pelajar Menerusi Persekitaran Pembelajaran Autentik Bervisual. Unpublished PhD. Universiti Teknologi Malaysia. Johor Bahru.

[19] Okamoto, T., \& Kayama, M. (2004). Collaborative Technology and New e-Pedagogy. Paper presented at the World Conference on E-Learning in Corporate, Government, Healthcare, and Higher Education 2004, Washington, DC, USA. http://www.editlib.org/ p/11114, https://doi.org/10.1109/icalt.2004.1357746

[20] Piaw, C. Y. (2011). Creating an Education Research Acculturation Theory for Research Implementation in School. Education and Urban Society.

[21] Sandberg, A., (2002). Preschool Teacher's Conceptions of Computers and Play. Information Technology in Childhood Education Annual. Department of Social Science, Malardalens University. 245-262

[22] Shadish, W. R., Cook, T. D., \& Campbell, D. T., (2002). Eksperimental And QuasiExperimental Designs For Generalized Causal Inference. Houghton Mifflin Company. 181

[23] Sharifah Nor \& Kamarul Azman (2011). Tahap Kesediaan Penggunaan ICT dalam Pengajaran dan Kesannya Terhadap Hasil Kerja dan Tingkah Laku Murid Prasekolah. Jurnal Pendidikan Malaysia Vol. 36(1) 25-34

[24] Teras, H., Leppisaari, I., Myllylä, M., \& Vainio, L. (2012). How to Support Collaborative Knowledge Building through Authentic Assessment in Online Education? Paper presented at the Society for Information Technology \& Teacher Education International Conference 2012, Austin, Texas, USA. http://www.editlib.org/p/39944

[25] Tervakari, A.-M., \& Silius, K. (2011). Towards More Authentic Learning in Hypermedia. International Journal of Emerging Technologies in Learning (iJET), 6(2011), 50-56. https://doi.org/10.1109/educon.2011.5773174

[26] Tham, R., \& Tham, L. (2013). Learning Effectiveness of Collaborative Learning in Singapore Higher Education - A Pilot Study. Paper presented at the Society for Information Technology \& Teacher Education International Conference 2013, New Orleans, Louisiana, United States. http://www.editlib.org/p/48261

[27] Turiman, P., Omar, J., Daud, A. M., \& Osman, K. (2012). Fostering the 21 st Century Skills through Scientific Literacy and Science Process Skills. Procedia - Social and Behavioral Sciences, 59(0), 110-116. https://doi.org/10.1016/j.sbspro.2012.09.253

[28] Wilson, J., \& Schwier, R. (2012). A Model of Authentic Learning Processes in Instructional Design. Paper presented at the Society for Information Technology \& Teacher Education International Conference 2012, Austin, Texas, USA. http://www.editlib.org/p/39757

[29] Woodley-Cook, J., Prabhudesai, V., \& Moloney, T. (2013). Use of embolic protective devices in treating acute arterial occlusions: an interventional radiology and vascular surgery 
Paper-Collaborative Learning in Authentic Environment Apps to Promote Preschool Basic Scientific...

collaborative learning experience. BMJ Case Reports, 2013. https://doi.org/10.1136/bcr2012-008132

\section{Authors}

Mohd Yunos, M. A. A. is a Educational Technology student at Faculty of Education, Universiti Teknologi Malaysia, Johor, 81310 Malaysia (e-mail: amerulfizik@yahoo.com).

Atan, N. A. is with the Universiti Teknologi Malaysia, Johor, 81310 Malaysia (email: azean@utm.my). She was UTM-MOOC \& OCW Manager (2013-2015) at Center for Teaching \& Learning, UTM.

Haruzuan, M. N. is with the Universiti Teknologi Malaysia, Johor, 81310 Malaysia (e-mail: nihra@utm.my). He is currently an IT Manager for Faculty of Education, UTM.

Mokhtar, M. is with the Universiti Teknologi Malaysia, Johor, 81310 Malaysia (email: p-mahani@utm.my). She is currently a Head Department of Educational Foundation \& Social Science, Faculty of Education, UTM.

Abu Samah, N. is with the Universiti Teknologi Malaysia, Johor, 81310 Malaysia (e-mail: norazrena@utm.my). She is currently a Senior Lecturer at Faculty of Education, UTM.

Article submitted 18 April 2016. Published as resubmitted by the authors 13 September 2016. 